University of Nebraska - Lincoln

DigitalCommons@University of Nebraska - Lincoln

Faculty Publications -- Chemistry Department Published Research - Department of Chemistry

3-2013

\title{
Implementing Process-Oriented, Guided-Inquiry Learning for the First Time: Adaptations and Short-Term Impacts on Students' Attitude and Performance
}

\author{
Anthony Chase \\ Purdue University, chase5@purdue.edu \\ Deblina Pakhira \\ University of Nebraska-Lincoln \\ Marilyne Stains \\ University of Nebraska-Lincoln, mstains2@unl.edu
}

Follow this and additional works at: https://digitalcommons.unl.edu/chemfacpub

Part of the Science and Mathematics Education Commons

Chase, Anthony; Pakhira, Deblina; and Stains, Marilyne, "Implementing Process-Oriented, Guided-Inquiry Learning for the First Time: Adaptations and Short-Term Impacts on Students' Attitude and Performance" (2013). Faculty Publications -- Chemistry Department. 60.

https://digitalcommons.unl.edu/chemfacpub/60

This Article is brought to you for free and open access by the Published Research - Department of Chemistry at DigitalCommons@University of Nebraska - Lincoln. It has been accepted for inclusion in Faculty Publications -Chemistry Department by an authorized administrator of DigitalCommons@University of Nebraska - Lincoln. 


\title{
Implementing Process-Oriented, Guided-Inquiry Learning for the First Time: Adaptations and Short-Term Impacts on Students' Attitude and Performance
}

\author{
Anthony Chase, Deblina Pakhira, and Marilyne Stains \\ Department of Chemistry, University of Nebraska-Lincoln, Lincoln, Nebraska 68588
}

Corresponding author — M. Stains, email mstains2@unl.edu

\begin{abstract}
Innovative, research-based instructional practices are critical to transforming the conventional undergraduate instructional landscape into a student-centered learning environment. Research on dissemination of innovation indicates that instructors often adapt rather than adopt these practices. These adaptations can lead to the loss of critical elements of the practice, which may affect its effectiveness. Process-oriented, guided-inquiry learning (POGIL) is a research-based instructional practice that has been widely disseminated for the past two decades. However, few studies have investigated practitioners' adaptations of POGIL and the impact of these adaptations on expected outcomes measured during recommended implementations of POGIL. In this study, we explore the impact of the implementation of POGIL in discussion sections of a general chemistry and an organic chemistry course on students' grades, retention, attitude toward chemistry, self-efficacy in chemistry, and attitude toward the learning environment provided in these courses. A quasi-experimental design was implemented and data were collected through valid and reliable surveys. Results indicate little to no impact on most measures, although positive trends favoring POGIL students were observed. Discussion of how this particular adaptation of POGIL could explain these results is presented, along with implications for research and practice.
\end{abstract}

Keywords: first-year undergraduate/general, second-year undergraduate, chemical education research, collaborative/cooperative learning, inquiry-based/discovery learning, student-centered learning

\section{Introduction}

Since the 1990s, science education research communities have developed and empirically tested numerous instructional practices grounded in theories on cognition, learning, and teaching (e.g., peer-led team learning, problem-based learning) for the postsecondary level. Some of these research-based instructional practices, which were originally developed within one discipline, have now been adopted by other disciplines. For example, process-oriented, guided-inquiry learning (POGIL) was originally created in chemistry ${ }^{1}$ but has now been implemented in many different fields, from anatomy and physiology, ${ }^{2}$ to aviation. ${ }^{3}$ This crossdisciplinary adoption is due in part to the empirical evidence supporting their effectiveness and the effective dissemination strategies used by the developers.

Many of the research-based instructional practices can be considered as innovations because they are still unknown to many practitioners and have not been adopted by the majority of institutions in the country. Research on dissemination of innovation points to several factors that may inhibit the adoption of an innovation, such as current level of satisfaction with one's own teaching, perceived characteristics of practice (e.g., perception that the practice has a steep learning curve), as well as discipline and departmental norms. ${ }^{4-7}$ Some of these factors result in faculty not adopting the practice altogether. Other faculty choose to implement the practice but adapt it to their situation based on their personal belief systems about teaching and learn- ing and the constraints of their environment. $5,8,9$ These adaptations, which may be necessary, can come with a reduced effectiveness when compared to the recommended implementation as some critical features can be unknowingly eliminated. ${ }^{10}$

Despite 10 years of development and dissemination, little has been reported on faculty members' adaptations of POGIL and the impacts of these adaptations on students' learning compared to reported impacts of the recommended implementation. This study attempts to fill this gap by presenting an example of how one chemistry department adapted POGIL for gateway chemistry courses and the short-term impacts this implementation had on students. A comparison is made between the impacts of this adaptation of POGIL and the impacts of the recommended implementation of POGIL previously reported in the literature.

\section{POGIL: Recommended Implementation and Reported Impacts}

POGIL is a student-centered instructional strategy that was developed by chemical educators in the late 1990s. In the following sections, the instructional structure and benefits of this practice are described.

\section{Structure}

POGIL is based on social constructivist learning theory and therefore involves students' developing their conceptual un- 
derstanding collaboratively. In an ideal POGIL session, students work in groups on carefully crafted activities that are based on the learning cycle. ${ }^{11}$ In the first part of the activity, students are provided with prerequisites, the learning objectives for the activity, and the criteria for success (orientation section). In the second section, students explore a model (e.g., a graph, or a table of data) through a series of questions (exploration). These questions help students develop an understanding of the concept by encouraging them to think critically about the model (this process is termed concept formation, or invention). In the next section, students reinforce and extend their understanding of the concept by answering questions on simple exercises and solving in-depth problems (application). Finally, students evaluate their learning by sharing the results of their group work with other groups in the class or the instructor, and reflect on their group performance.

POGIL developers recognize that implementation of this practice will differ from classroom to classroom depending on instructors as well as institutional, departmental, and course contexts. However, they have published a manual to assist faculty. ${ }^{12}$ POGIL-based textbooks have also been published at all levels of the undergraduate chemistry curriculum ${ }^{13}$ and a guide has been created to help faculty develop their own POGIL activities. ${ }^{14}$ POGIL developers identified four key characteristics that describe a POGIL implementation: ${ }^{14}$

1.Students are expected to work collaboratively, generally in groups of three or four.

2.Activities that the students use are POGIL activities, specifically designed for POGIL implementation.

3.Students work on the activity during class time with a facilitator present.

4.The dominant mode of instruction is not lecture- or instructor-centered; the instructor serves predominantly as a facilitator of student learning.

Moreover, these developers have identified four additional characteristics that are typical of POGIL implementation: ${ }^{14}$

5.Students have assigned roles within their groups.

6.The activity is designed to be the first introduction to the topic or specific content.

7.Students are not expected to have worked on any part of the activity prior to class meeting time.

8.Groups are expected to complete all of the Critical Thinking Questions (or equivalently designated questions) during class (in no more than about $40 \mathrm{~min}$ of actual working time), but they are not expected to work on any of the Exercises or Problems.

It is also recommended that POGIL replace the traditional lectures. ${ }^{15}$

\section{Impact on Grade}

The impact of POGIL on students' grades has been the most widely studied and reported outcome. ${ }^{1,16-20}$ The majority of studies report strong positive impacts on students' exams and overall course grades. ${ }^{1,-19}$ In particular, it has been demonstrated that students who experience POGIL perform statistically better on the standardized American Chemical Society (ACS) exams than students who experience traditional lectures. ${ }^{16,18}$ However, some studies report mixed results. For example, Rajan and Marcus explored the impact of POGIL in an introductory chemistry course for nonscience majors and saw a statistically significant difference between the control and POGIL groups on the final exam but not on the midterm exams. ${ }^{20}$ Other studies reporting mixed results indicate that variations in implementation may be a factor. ${ }^{16,18}$

\section{Impact on Retention}

Retention in POGIL studies have mostly been measured in terms of the rate of students who earn a course letter grade of D, F, or W. These studies have found that POGIL decreases dramatically the DFW rate when compared to traditional lectures. ${ }^{1,} 18$ Hanson and Wolskill ${ }^{19}$ also demonstrated an increase in POGIL sections' attendance at the general chemistry level and an increase in the enrollment in the organic chemistry course following the general chemistry course. While the number of studies is limited, a consensus seems to be emerging that POGIL improves retention.

\section{Impact on Students' Attitude and Self-Efficacy}

According to one of the theoretical tenets behind POGIL, ${ }^{21}$ an expected outcome of POGIL is an increase in students' attitude toward chemistry, defined as the "thought and feelings about course experiences and about chemistry as a discipline". ${ }^{22}$ However, very few studies have investigated this impact. Moreover, these few investigations are based on instructor-designed questionnaires rather than valid and reliable surveys, except for one study. ${ }^{20}$ Therefore, the extent of the impact of POGIL on students' attitude toward chemistry is unclear.

Finally, an increase in self-efficacy in chemistry (i.e., one's confidence in one's ability to perform tasks in chemistry ${ }^{23}$ ) should also be observed as a result of POGIL implementation. ${ }^{22}$

\section{Purpose and Research Questions}

The goal of this study is to investigate the impact of adapting rather than adopting POGIL in chemistry gateway courses on students' achievements, retention, self-efficacy, attitude toward chemistry and their learning environment. The research question explored in this study is the following:

Did the adaptation of POGIL presented in this study impact students' (i) grades, (ii) retention, (iii) attitude toward chemistry, (iv) attitude toward their learning environment, and (v) self-efficacy in a similar way than reported impacts for the recommended implementation of POGIL?

\section{Methods}

\section{Setting}

This study was conducted at a large, four-year, public, research university in the United States of America. Two courses were targeted by the POGIL implementation: the first semester of general chemistry and the first semester of organic chemistry. These courses consisted of three 50-min lectures per week and one 50-min discussion section. Typically, the lecture was attended by 200 students and the discussion sections were designed for 30 students. The laboratory was a separate course.

\section{Adaptation of POGIL}

A group of faculty in the chemistry department decided to implement POGIL after discussions among colleagues, including one of the organic faculty had been implementing it for four semesters in the discussion sessions of the course. Because these faculty members were not teaching the lectures, it was decided that POGIL would be tested in the discussion sections. Faculty hired undergraduate students (one per discussion section) who already successfully passed the course to help facilitate the POGIL sessions (e.g., answering students' questions, probing, and guiding them). 
A certified POGIL workshop facilitator provided an oncampus, 3-h workshop on the implementation of POGIL to both faculty and the newly hired undergraduate students. Two faculty members (one in the first semester of general chemistry and one in the first semester of organic chemistry) implemented POGIL in all the discussion sessions they were responsible for. The organic chemistry faculty had implemented POGIL for four semesters prior to this study but had not been formally trained. The context of this study therefore represents the first time that the organic faculty implemented POGIL after receiving training and the first time the general chemistry faculty implemented POGIL.

The adaptions of POGIL made by the faculty satisfied characteristics 1-3 and 5-8 previously described (see above and Table 1). Characteristic 6 was met for most students as most discussion sessions were scheduled prior to the complete presentation of the concepts in the lecture. Characteristic 4 was only adopted in the discussion sections; lectures were teachercentered. The general chemistry faculty also used a self-assessment worksheet. ${ }^{12}$ Therefore, most of the features highlighted by POGIL designers were kept during implementation.

Adaptations were also made with respect to the POGIL activities. The general chemistry faculty designed his POGIL activities. While they were specifically designed for the POGIL implementation (characteristic 2), they did not fulfill all the expected criteria for POGIL activities ${ }^{14}$ (see Table 2). In particular, the general chemistry activities did not consistently present students with key questions and a complete application section (i.e., they typically contained simple exercises but no in-depth problems). The organic faculty used POGIL activities from a published POGIL workbook and adapted them to fit the curriculum and the time frame of the discussion. These activities did not include an orientation section, which is consistent with the published POGIL workbook the faculty used, ${ }^{24}$ and the application section was missing in a quarter of the activities (Table 2). Because end-of-chapter problems were assigned as homework

Table 1. Adaptations Made in This Study Compared to Recommended Implementation of POGIL

\begin{tabular}{|c|c|}
\hline $\begin{array}{l}\text { Characteristics of } \\
\text { Recommended } \\
\text { Implementation }\end{array}$ & $\begin{array}{l}\text { Characteristics } \\
\text { of Adapted } \\
\text { Implementation }\end{array}$ \\
\hline $\begin{array}{l}\text { Students are expected to work collaboratively, } \\
\text { generally in groups of three or four. }\end{array}$ & $\begin{array}{l}\text { Present in } \\
\text { this study }\end{array}$ \\
\hline $\begin{array}{l}\text { Activities that the students use are POGIL } \\
\text { activities, specifically designed for POGIL } \\
\text { implementation. }\end{array}$ & $\begin{array}{l}\text { Present in } \\
\text { this study } \\
\text { to some extent }\end{array}$ \\
\hline $\begin{array}{l}\text { Students work on the activity during class } \\
\text { time with a facilitator present. }\end{array}$ & $\begin{array}{l}\text { Present in } \\
\text { this study }\end{array}$ \\
\hline $\begin{array}{l}\text { The dominant mode of instruction is not lecture } \\
\text { or instructor-centered; the instructor serves } \\
\text { predominantly as a facilitator of student learning. }\end{array}$ & $\begin{array}{l}\text { Present in } \\
\text { this study in } \\
\text { discussions only }\end{array}$ \\
\hline $\begin{array}{l}\text { Students have assigned roles within their } \\
\text { groups. }\end{array}$ & $\begin{array}{l}\text { Present in } \\
\text { this study (GC) }\end{array}$ \\
\hline $\begin{array}{l}\text { The activity is designed to be the first } \\
\text { introduction to the topic or specific content }\end{array}$ & $\begin{array}{l}\text { Present in } \\
\text { this study }\end{array}$ \\
\hline $\begin{array}{l}\text { Students are not expected to have worked on any } \\
\text { part of the activity prior to class meeting time. }\end{array}$ & $\begin{array}{l}\text { Present in } \\
\text { this study }\end{array}$ \\
\hline $\begin{array}{l}\text { Groups are expected to complete all of the } \\
\text { Critical Thinking Questions during class, but } \\
\text { they are not expected to work on any of the } \\
\text { Exercises or Problems. }\end{array}$ & $\begin{array}{l}\text { Present in } \\
\text { this study }\end{array}$ \\
\hline
\end{tabular}

Table 2. Content of the Instructor-Designed and -Adapted POGIL Activities

\begin{tabular}{lccr}
\hline & \multicolumn{2}{c}{$\begin{array}{c}\text { Extent of Implementation of POGIL } \\
\text { Learning Cycle Elements, Average (SD) }\end{array}$} \\
\cline { 2 - 4 } Course & \multicolumn{3}{c}{ Exploration/Concept } \\
\hline General Chemistry & $2.0(0.0)$ & $1.5(0.7)$ & $0.8(0.6)$ \\
Organic Chemistry & $0.0(0.0)$ & $2.0(0.0)$ & $1.5(0.9)$ \\
\hline
\end{tabular}

a. The presence of a learning cycle element was quantified as follows: $0=$ absent, 1 = partially present, 2 = completely present.

b. These data are averages (with standard deviations) of the extent of POGIL implementation over all the POGIL worksheets used for the course.

in both courses, these problems may have been considered by the POGIL instructors as part of the application component.

\section{Participants}

The participants were students enrolled in one lecture section of the first semester of a general chemistry course and one lecture section of the first semester of an organic chemistry course $(N=271$ and $N=182$, respectively, excluding students with a grade of incomplete). POGIL was implemented in three of the nine discussion sections in the general chemistry course ( $N=93$ POGIL students) and three of the five discussion sections in the organic chemistry course ( $N=100$ POGIL students). Students enrolled in the other discussion sections represent the control group. During these discussions, the instructors, who were faculty members in the chemistry department, solved end-of-chapter problems assigned by the lecture instructors with minimal input from students. No undergraduate facilitators were present in the control sessions. Content coverage between the POGIL and control discussion sessions was not controlled for. However, they both covered content based on what was done in the lecture that week, which was common to both of these groups.

Students enrolled in the discussion sections based on their schedule and had no knowledge of the type of instruction they would be exposed to prior to registering.

\section{Data Collected}

Grade and discussion section attendance data were collected from the lecture instructors, with the exception that discussion section attendance data for the general chemistry course was not provided. The lecture instructors had no knowledge of students' assignments to discussion sections.

Students' attitude toward chemistry as an academic subject matter was evaluated through the Attitude toward the Subject of Chemistry Inventory (ASCI). ${ }^{25}$ This survey evaluates students' attitude toward chemistry along five variables: fear, interest and utility, intellectual accessibility, anxiety, and emotional satisfaction. ${ }^{25}$

The Chemistry Attitude and Experiences Questionnaire (CAEQ) measured students' attitude toward chemistry from a societal perspective (subscales include attitude toward chemists, skills of chemists, attitude toward chemistry in society, leisure interest in chemistry, and career interest in chemistry), students' self-efficacy, and students' attitude toward their learning environments (lecture, discussion, and laboratory). ${ }^{23}$

Both surveys are reliable and valid. They were implemented at the beginning and end of the semester and collected during the laboratory for the general chemistry course and lecture for the organic chemistry course, following lecture instructors' preferences. 

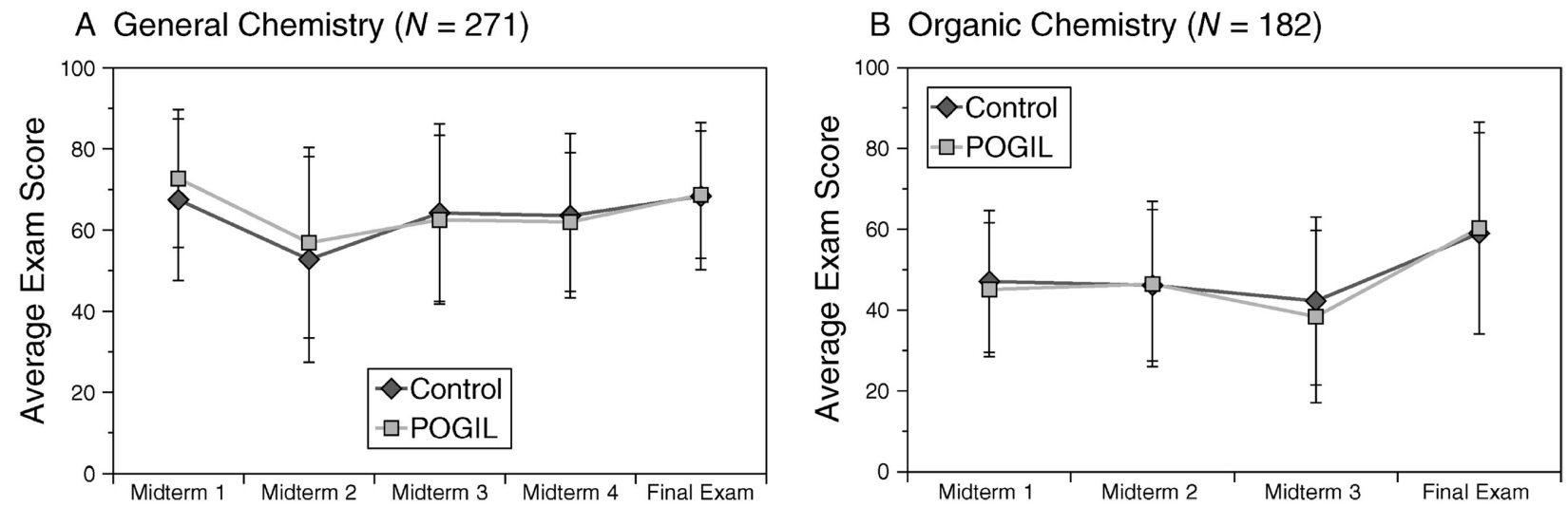

Figure 1. Control group and POGIL group students' average scores on midterm and final exams in the (A) General Chemistry, and (B) Organic Chemistry courses. (Error bars represent standard deviations.)

a) General Chemistry $(\mathrm{N}=\mathbf{2 7 1})$

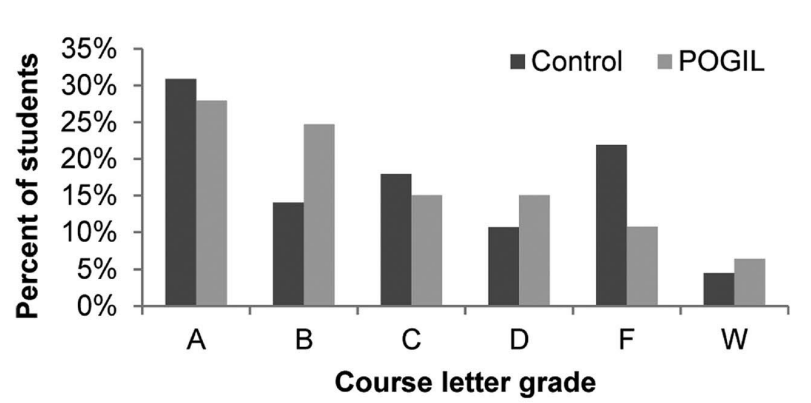

b) Organic Chemistry ( $\mathrm{N}=182)$

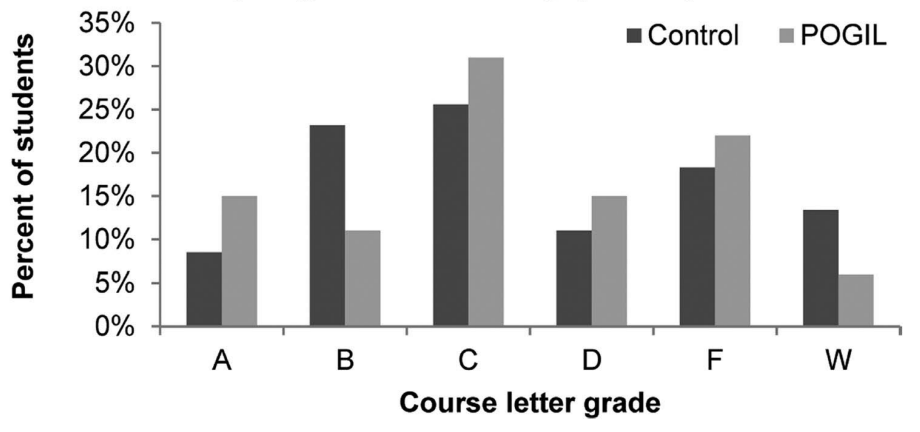

Figure 2. Distribution of course letter grades in the (A) General Chemistry, and (B) Organic Chemistry courses.
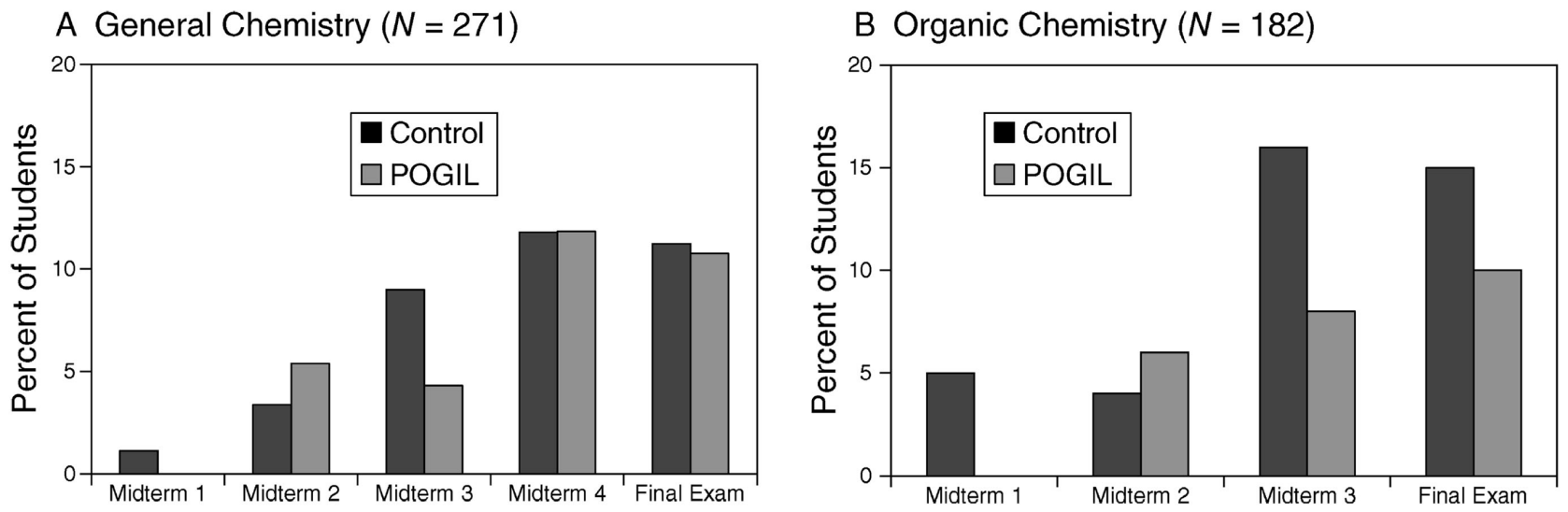

Figure 3. Percentage of students who missed exams in the (A) General Chemistry, and (B) Organic Chemistry courses.

Surveys were collected on a voluntary basis. No extra credit was provided. A $\chi^{2}$-analysis revealed no statistically significant relationship between proficiency and survey participation.

\section{Data Analysis}

Data sets were cleaned before data analysis took place. For example, only students who answered both pre- and postsurveys were included in the study. Statistical analyses were conducted to evaluate the extent to which the POGIL and control groups in the general and organic chemistry courses were different and to ensure that assumptions were met for all the statistical tests employed in the analyses of the data. The results are presented in the Supporting Information and indicate no differences between the POGIL and control populations in both courses, acceptable internal consistency of the data, and that assumptions were met for the statistical tests used.

\section{Results and Discussion}

Findings associated with each aspect of the research question are presented in the following sections. In the rest of the paper, GC refers to general chemistry and OC to organic chemistry.

\section{Impact on Grade}

ANOVA tests on students' grades on midterm and final exams in both courses indicate no differences between the control and POGIL group, except for the first exam in the GC course, $F(268,1)=4.636, p=0.032$ (see Figure 1 ). 
In the GC course, a $\chi^{2}$ analysis on the distribution of participants by letter grades revealed a statistically significant relationship between the type of students (POGIL or control) and students' letter grade in the course (Figure 2A). In particular, there were significantly more POGIL students who obtained the letter grade B than control students, and significantly fewer POGIL students who received the letter grade $\mathrm{F}$ than control students, $X^{2}(257,4)=9.629, p=0.048, V=0.194$. This trend was not observed in the OC course (Figure 2B). The implementation of POGIL in the discussion sections therefore had some positive impact on grades in the GC course and no impact (positive or negative) in the OC course.

\section{Impact on Students' Retention}

DFW rates of the control group students and POGIL students were not statistically different in both courses. In the OC course, the rates were quasi-identical (43\% for POGIL and $42 \%$ for control). In the GC course, DFW rate for POGIL students was $5 \%$ smaller than for control students ( $32 \%$ vs $37 \%$ ).

Retention was also evaluated by monitoring students' attendance in discussion sections. A statistically significant difference was measured in the OC course, with POGIL students attending on average 1.47 more sessions than control students (out of 12 total sessions): $F(182,1)=10.876 ; p=0.001$. Unfortunately, attendance to GC discussion sections was not provided.

Finally, perseverance in the course was measured by the proportion of students who missed midterm and final exams. As Figure 3 illustrates, POGIL students in both courses missed fewer exams as the semester proceeded than control group students, although no statistical significance was observed.

In general, the different measures of retention evaluated in this study indicate minimal positive impact of this implementation of POGIL.

\section{Impact on Students' Attitude toward Chemistry}

Impact of POGIL on students' attitude toward chemistry as a subject matter (ASCI) and toward chemistry from a societal perspective (CAEQ) was evaluated using several statistical analyses. Analysis of potential differences between the two groups of students on premeasures indicated that both populations were statistically similar, except for the GC course in which students in the control group scored lower on emo- tional satisfaction, $F(179,1)=6.173, p=0.014$, and higher on anxiety than POGIL students, $F(179,1)=6.293, p=0.013$ (effect size $=0.18$ and power $=0.67$ for both tests).

First, paired-sample $t$-tests were performed to evaluate separately the impact of the course on POGIL and control students' attitude. Applying the Bonferroni correction $(p=0.01)$, it was found that in both courses, control group and POGIL students did not significantly change their attitude toward chemistry from a societal perspective (CAEQ) over the semester. It was also found that OC students in the control and POGIL groups did not significantly change their attitude toward chemistry as a subject matter (ASCI). However, while the POGIL students in the GC course also did not significantly change their attitude toward chemistry as a subject matter during the semester, GC students in the control group did. Indeed, control group students' emotional satisfaction as well as interest and utility for chemistry significantly decreased, $t(111,110)$ $=3.014, p=0.003, d=0.29,1-\beta=0.86$, and $t(111,110)=4.135, p$ $<0.001, d=0.39,1-\beta=0.98$, respectively. Moreover, their anxiety about chemistry significantly increased throughout the semester, $t(111,110)=-3.480, p=0.001, d=0.33,1-\beta=0.93$.

Repeated-measure ANOVA tests were performed to evaluate the differences in the change of means over the course of the semester between control and POGIL students (Table 3). At the GC level, no significant differences were observed for either survey. In the OC course, two variables indicated statistically significant differences for the change in means during the semester between POGIL and control students. Indeed, the increase in POGIL students' attitude toward the skills of chemists was significantly different than the corresponding decrease in the control group $(1-\beta=0.55)$. Moreover, the decrease in POGIL students' anxiety toward chemistry as a subject matter was significantly different than the increase in anxiety for the control group $(d=0.30,1-\beta=0.51)$.

Certain studies have shown that repeated-measure ANOVA test may falsely reject the null hypothesis. ${ }^{26}$ Therefore, ANCOVA tests were also performed in order to evaluate the impact of the POGIL treatment on students' attitude while controlling for pretreatment differences. In other words, postsurvey means for each variable of the surveys were compared between control group and POGIL group while presurvey means of these variables were controlled for. The results of

Table 3. Pre-Post Mean Differences and Results of Repeated-Measure ANOVA Analysis for the ASCI and CAEQ Surveys

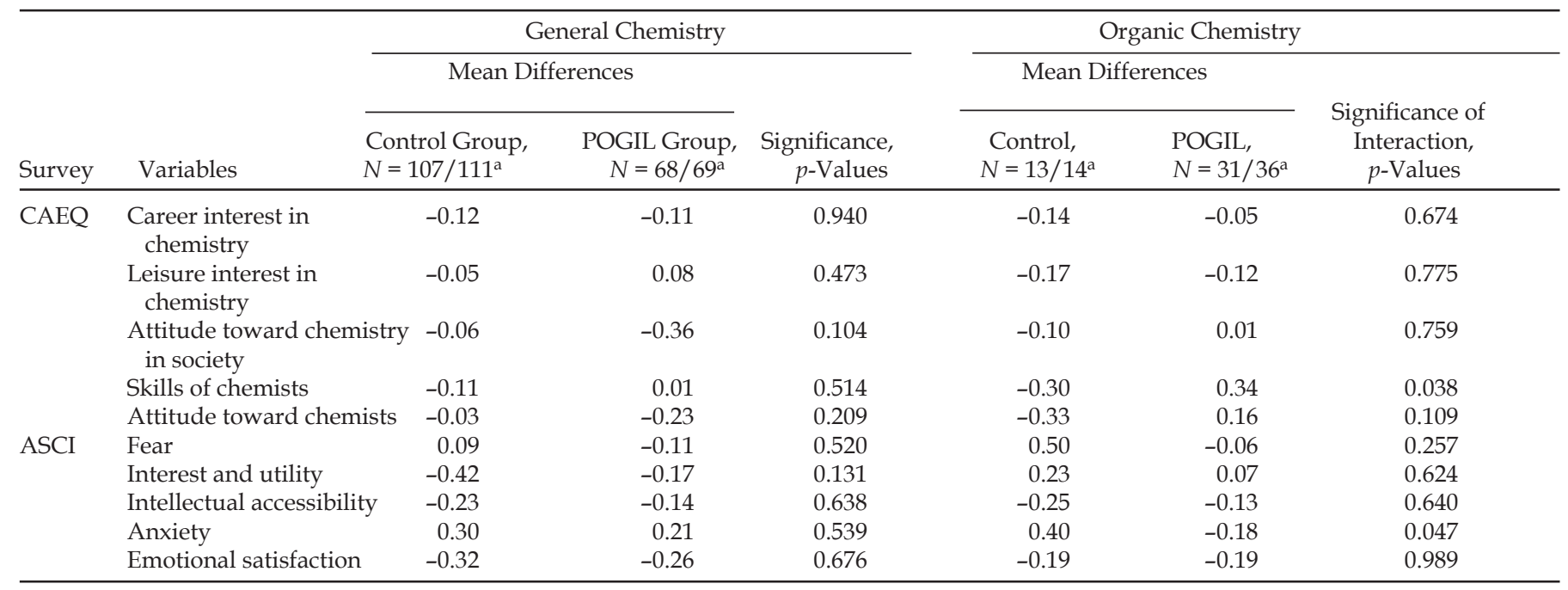

a. Number of CAEQ responses/Number of ASCI responses. 
A General Chemistry $(N=171)$

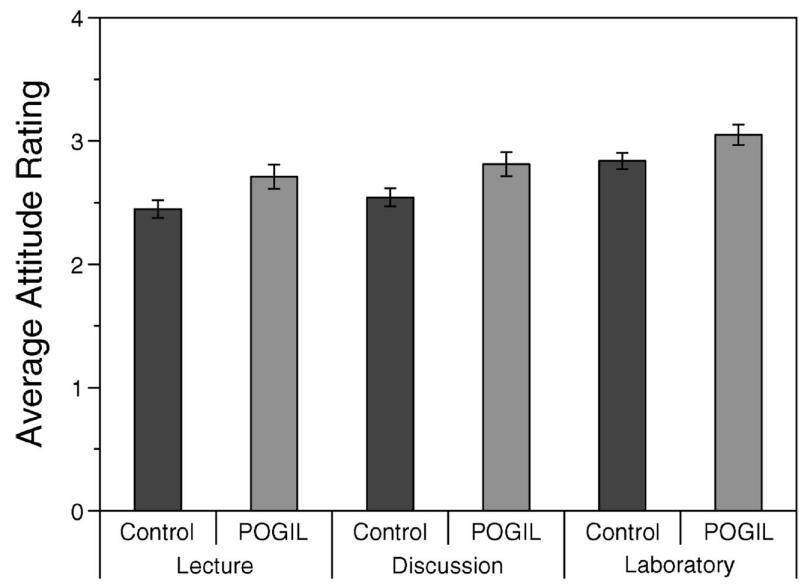

B Organic Chemistry $(N=45)$

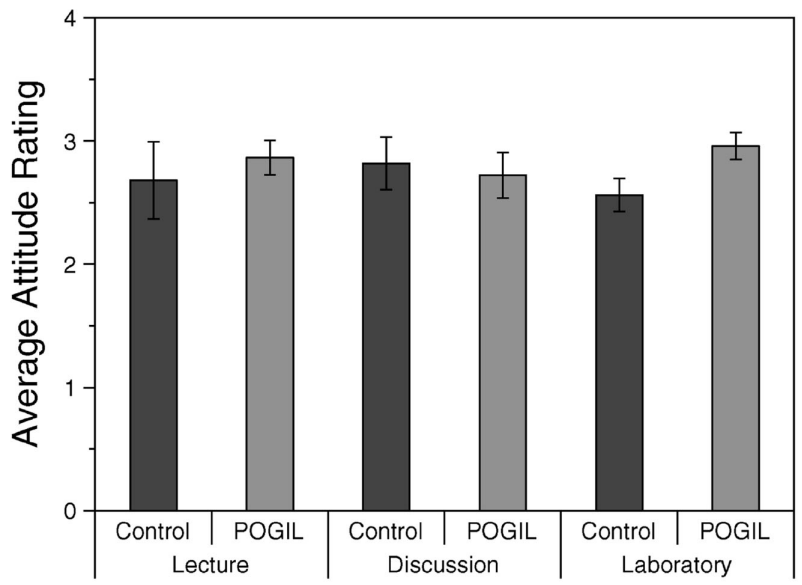

Figure 4. Students' attitude ratings toward their learning environments: scores range from 1 (strongly agree) to 5 (strongly disagree).

these analyses are presented in Table 4. Only one statistically significant difference was observed between the two groups: the measure of interest and utility was higher for the POGIL group than the control group in the GC course.

In summary, this particular implementation of POGIL had little to no impact on students' attitude toward chemistry when compared to control students.

\section{Impact on Students' Attitude toward Their Learning Environment}

Through the CAEQ survey, students evaluated their attitude toward the learning environment in the lecture, discussion, and laboratory. Only results obtained on the post-CAEQ survey were used for this analysis, as students had little to no experience with these environments at the beginning of the semester.

In the GC course, POGIL students had a significantly higher attitude toward all three environments when compared to students in the control group (see Figure 4A): Lecture, $F(167,1)=4.912, p=0.028$; Discussion, $F(170,1)=4.890, p=$ 0.028; Laboratory, $F(170,1)=4.001, p=0.047$. In the OC course, POGIL students only had a significantly higher attitude toward the laboratory when compared to control students, $F(44$, 1 ) $=4.256, p=0.045$ (see Figure $4 \mathrm{~B}$ ). It is unclear why POGIL students rated higher these other learning environments provided in the course; thus, further research is needed to explore these findings.

Table 4. Estimated Postsurvey Marginal Means Resulting from ANCOVA Analysis of the ASCI and CAEQ Surveys

\begin{tabular}{|c|c|c|c|c|c|c|c|}
\hline \multirow[b]{3}{*}{ Survey } & \multirow[b]{3}{*}{ Variables } & \multicolumn{3}{|c|}{ General Chemistry } & \multicolumn{3}{|c|}{ Organic Chemistry } \\
\hline & & \multicolumn{2}{|c|}{ Marginal Means } & \multirow[b]{2}{*}{$\begin{array}{l}\text { Significance, } \\
P \text {-Values }\end{array}$} & \multicolumn{2}{|c|}{ Marginal Means } & \multirow{2}{*}{$\begin{array}{l}\text { Significance } \\
\text { of Interaction, } \\
P \text {-Values }\end{array}$} \\
\hline & & $\begin{array}{l}\text { Control, } \\
N=107 / 111^{\mathrm{a}}\end{array}$ & $\begin{array}{l}\text { POGIL, } \\
N=68 / 69^{a}\end{array}$ & & $\begin{array}{l}\text { Control, } \\
N=13 / 14^{\mathrm{a}}\end{array}$ & $\begin{array}{l}\text { POGIL, } \\
N=3 / 36^{\mathrm{a}} 1\end{array}$ & \\
\hline \multirow[t]{5}{*}{ CAEQ } & Career interest in chemistry & 4.84 & 4.92 & 0.609 & 5.32 & 5.39 & 0.758 \\
\hline & Leisure interest in chemistry & 5.09 & 5.12 & 0.837 & 5.34 & 5.38 & 0.875 \\
\hline & $\begin{array}{l}\text { Attitude toward chemistry } \\
\text { in society }\end{array}$ & $6.29^{b}$ & $5.88^{b}$ & $\mathrm{~N} / \mathrm{A}$ & $6.03^{b}$ & $6.28^{b}$ & $\mathrm{~N} / \mathrm{A}$ \\
\hline & Skills of chemists & 5.16 & 5.32 & 0.285 & 4.91 & 5.48 & 0.053 \\
\hline & Attitude toward chemists & 5.00 & 4.90 & 0.480 & 4.71 & 5.22 & 0.065 \\
\hline \multirow[t]{5}{*}{ ASCI } & Fear & 3.58 & 3.49 & 0.723 & 3.75 & 3.68 & 0.858 \\
\hline & Interest and utility & 4.89 & 5.22 & 0.028 & 5.45 & 5.32 & 0.643 \\
\hline & Intellectual accessibility & 3.44 & 3.57 & 0.397 & 3.40 & 3.38 & 0.932 \\
\hline & Anxiety & 4.33 & 4.09 & 0.065 & 4.61 & 4.29 & 0.223 \\
\hline & Emotional satisfaction & 4.20 & 4.42 & 0.147 & 4.37 & 4.20 & 0.547 \\
\hline
\end{tabular}

a. Number of CAEQ responses/number of ASCI responses.

b. Actual postsurvey means: assumptions for ANCOVA were violated.

Table 5. Comparison of Outcomes between Present Adaptation and Recommended Implementation of POGIL

\begin{tabular}{|c|c|c|}
\hline Variables & Published Results & Results of Current Study \\
\hline Grade & Mostly positive impact & $\begin{array}{l}\text { Some positive impact in general chemistry } \\
\text { Neutral in organic chemistry }\end{array}$ \\
\hline Retention & $\begin{array}{l}\text { Decrease in DFW rates } \\
\text { Increased attendance }\end{array}$ & $\begin{array}{l}\text { No difference in DFW rates } \\
\text { Increased attendance }\end{array}$ \\
\hline Attitude toward chemistry & Positive change hypothesized but not established & Inconclusive positive trends \\
\hline Learning environments & $\begin{array}{l}\text { Positive change hypothesized but not established } \\
\text { environments, especially the laboratory }\end{array}$ & Increased positive attitude toward all learning \\
\hline Self-efficacy & Positive change hypothesized but not established & No impact \\
\hline
\end{tabular}


Impact on Students' Self-Efficacy

The same statistical analyses employed to investigate differences in students' attitude toward chemistry were used to evaluate impact of POGIL on students' self-efficacy in chemistry. There were no statistical differences observed between and within groups. Therefore, this implementation of POGIL did not improve or reduce students' self-efficacy in chemistry.

\section{Conclusions and Implications}

In this study, we explored the impact on students of the implementation of POGIL during the discussion sections of a general chemistry course and an organic chemistry course. Results indicate that this adaptation of POGIL had limited to no impact on students' grades, attitude toward chemistry, and self-efficacy compared to students in the control group, although some positive trends were observed. However, this implementation enhanced students' perseverance as well as their attitude toward the learning environments provided in the course. Table 5 summarizes the differences between the outcomes of the present adaptation of POGIL and published outcomes of recommended implementation of POGIL. It is important to note that POGIL was implemented in a small proportion of the courses, which might explain the few differences observed.

\section{Implications for Research}

The mixed results of this adapted implementation of POGIL may result from some of the adaptations that were made. Although most principles prescribed for POGIL implementation were observed, some were not. In particular, POGIL was implemented in discussion rather than lecture and the activities did not contain all required sections (see Table 1). This study thus suggests that more research is required to explore the relationship between fidelity of implementation of POGIL and impact on students. Exploring practitioners' various adaptations of POGIL and their impact on students' performance could lead to a better understanding of the components of POGIL that contribute most to enhancing grades and retention.

Most POGIL studies were carried out either over a long period of time or after piloting the practice for a couple of semesters. Therefore, the time frame of this study, first semester of implementation, could also explain the mixed results. Studies investigating the evolution of impacts of POGIL over time would inform practitioners interested in adopting this innovation on expected time frame before impacts can be observed. Studies should also investigate whether certain factors, such as instructors' training in POGIL, affect this timing.

The lack of impact of POGIL on students' attitude toward chemistry and self-efficacy reported in this study could be explained by the factors just described. However, few studies exploring high fidelity of implementation of POGIL have measured these affective variables through valid and reliable surveys, even though these are expected outcomes of POGIL. Further research is thus needed to explore the relationships between fidelity of implementation of POGIL and impact on these affective variables.

Finally, one surprising result of this study was the positive effect of POGIL on students' attitude toward other learning environments (lecture and laboratory) than the POGIL one (discussion). To the authors' knowledge, this connection has not been reported before and may merit further study.
Implications for Practice

This study should not discourage instructors from implementing POGIL. Indeed, the enhanced attendance of POGIL students in the discussion sections demonstrated in this study is a desirable outcome that is difficult to obtain with traditional teaching methods. However, this study highlights several factors that instructors interested in this practice should be cognizant of.

First, adaptations to the prescribed POGIL implementation may affect the expected impacts on students. Therefore, instructors should carefully inform themselves about the prescribed implementation of POGIL. Interested instructors should consult the POGIL Web site, which provides numerous resources for implementation. ${ }^{13}$ These careful analyses will help instructors identify ways to implement POGIL to fit their context while also taking into account POGIL principles.

Second, the results of this study indicate that instructors implementing POGIL should not presume to observe all expected outcomes after the first implementation. This study indicates that a delay may exist between first implementation and positive outcomes for students.

Finally, the present study demonstrates that POGIL does not negatively affect students' learning when compared to traditional teacher-centered learning environment and has the potential, in fact, to enhance it. These results along with the underlying principles of POGIL, which are based on established learning theories, should encourage instructors to test POGIL in their classrooms.

\section{Supporting Information}

Additional data from the General Chemistry and Organic Chemistry ASCI and CAEQ surveys is presented following the References.

Acknowledgment - We thank all the participants in the study, including the lecture and discussion instructors. We also thank the College of Science and Mathematics at the University of Massachusetts, Boston for funding the original implementation of POGIL and partly supporting the work presented in this article.

\section{References}

1. Farrell, J. J., Moog, R. S., Spencer, J. N. J. Chem. Educ. 1999, 76,570

2. Brown, P. J. P. Adv. Physiol. Educ. 2010, 34, 150

3. Vacek, J. Col. Aviat. Rev. 2011, 29, 78

4. Rogers, E. M. Diffusion of Innovations, 5th ed., Free Press: New York, 2003.

5. Gess-Newsome, J., Southerland, S. A., Johnston, A., Woodbury, S. Am. Educ. Res. J. 2003, 40, 731

6. Seymour, E., DeWelde, K., Fry, C. Determining Progress in Improving Undergraduate STEM Education: The Reformers' Tale. A white paper commissioned for the forum, Characterizing the Impact and Diffusion of Engineering Education Innovations, February 7-8, 2011, National Academy of Engineering of the National Academies: Washington, DC, 2011. http://www.nae.edu/File.aspx?id=36664 (accessed Feb 2013). 
7. Bunce, D. M., Havanki, K., VandenPlus, J. In Process Oriented Guided Inquiry Learning (POGIL), Moog, R. S., Spencer, J. N., eds., American Chemical Society: Washington, DC, 2008, p 100.

8. Henderson, C., Dancy, M. H. Phys. Rev. Spec. Top.-Phys. Educ. Res. 2007, 3, 020102

9. Rogers, E. M. Diffusion of Innovations, 5th ed., Free Press: New York, 2003.

10. Turpen, C., Finkelstein, N. D. Phys. Rev. Spec. Top.-Phys. Educ. Res. 2009, 5020101

11. Atkin, J. M., Karplus, R. Discovery or Invention? In A Love of Discovery: Science Education - The Second Career of Robert Karplus, Kluwer Academic/Plenum Publishers: New York, 2002, p 83.

12. Hanson, D. POGIL Instructor's Guide, Pacific Crest: Lisle, IL, 2006.

13. POGIL. Process Oriented Guided Inquiry Learning, published online, 2011. http://pogil.org/ (accessed Feb 2013).

14. POGIL. Writingand Submitting Activities, published online, 2011. http:// pogil.org/resources/writing-submittingpogil-activities (accessed Feb 2013).

15. Eberlein, T., Kampmeier, J., Minderhout, V., Moog, R. S., Platt, T., Varma-Nelson, P., White, H. B. Biochem. Mol. Biol. Educ. 2008) 36, 262
16. Daubenmire, P., Bunce, D. M. In Process Oriented Guided Inquiry Learning (POGIL), Moog, R. S., Spencer, J. N., eds., American Chemical Society: Washington, DC, 2008, p 87.

17. Ruder, S., Hunnicutt, S. In Process Oriented Guided Inquiry Learning (POGIL), Moog, R. S., Spencer, J. N., eds., American Chemical Society: Washington, DC, 2008, p 133.

18. Straumanis, A., Simons, E. In Process Oriented Guided Inquiry Learning (POGIL), Moog, R. S., Spencer, J. N., eds., American Chemical Society: Washington, DC, 2008, p 226.

19. Hanson, D., Wolfskill, T. J. Chem. Educ. 2000, 77, 120

20. Rajan, N., Marcus, L. Chem. Educat. 2009, 14, 85

21. Prince, M. J. Eng. Educ. 2004, 93, 223

22. Bauer, C., Cole, R. Assessment Handbook, Part 1. published online, 2005. http://www.pogil.org/post-secondary/anapogil/course-assessment/handbook (accessed Feb 2013).

23. Coll, R., Dalgety, J., Slater, D. Chem. Educ. Res. Pract. 2002, 3,19

24. Straumanis, A. Organic Chemistry: A Guided Inquiry, 2nd ed., Houghton Mifflin: Boston, MA, 2008.

25. Bauer, C. J. Chem. Educ. 2008, 85, 1440

26. Dimitrov, D. M., Rumrill, P. D. Work 2003, 20, 159 


\section{Supplemental Materials}

Table 1. Skewness and Kurtosis values for General Chemistry and Organic Chemistry ASCI and CAEQ surveys

\begin{tabular}{|c|c|c|c|c|c|}
\hline \multirow{1}{*}{ Survey } & Variables & \multicolumn{2}{c|}{ General Chemistry } & \multicolumn{2}{c|}{ Organic Chemistry } \\
& Skewness & Kurtosis & Skewness & Kurtosis \\
\hline \multirow{5}{*}{ CAEQ(Pre) } & Career interest in chemistry & -0.585 & 1.432 & -1.085 & 1.832 \\
& Leisure interest in chemistry & -0.105 & -0.343 & -0.540 & 0.295 \\
& Attitude towards chemistry in & -1.285 & 1.142 & -1.849 & 4.525 \\
& Society & & & & \\
& Skills of chemists & -1.221 & 4.676 & -0.413 & 0.111 \\
& Attitude towards chemists & -0.572 & 0.663 & -0.497 & 0.346 \\
\hline \multirow{5}{*}{ CAEQ(Post) } & Career interest in chemistry & -0.615 & 0.948 & -0.736 & 0.748 \\
& Leisure interest in chemistry & -0.412 & 1.049 & 0.075 & -1.097 \\
& Attitude towards chemistry in & -1.470 & 2.258 & -0.726 & -0.797 \\
& society & & & & \\
& Skills of chemists & -0.589 & 1.099 & -0.051 & -1.205 \\
& Attitude towards chemists & -0.508 & 0.547 & -0.179 & -0.377 \\
\hline \multirow{5}{*}{ ASCI(Pre) } & Fear & 0.019 & -0.689 & -0.505 & -0.291 \\
& Interest and utility & -0.370 & 0.009 & -1.016 & 1.902 \\
& Intellectual accessibility & 0.169 & 0.890 & -0.382 & -0.077 \\
& Anxiety & -0.216 & 0.148 & 0.121 & 0.172 \\
& Emotional satisfaction & 0.023 & 0.302 & -0.116 & -0.367 \\
\hline \multirow{5}{*}{ ASCI(Post) } & Fear & 0.123 & -0.569 & -0.315 & 0.365 \\
& Interest and utility & -0.068 & -0.390 & -0.436 & 0.378 \\
& Intellectual accessibility & -0.042 & 0.078 & -0.385 & -0.373 \\
& Anxiety & -0.220 & 0.356 & -0.212 & -0.301 \\
& Emotional satisfaction & -0.170 & 0.403 & 0.321 & -0.199 \\
\hline
\end{tabular}

Skewness and Kurtosis values should be within the range of \pm 1.0 for the distribution to be considered a normal distribution. This test is followed by the Levene's test of homogeneity to assess the equality of variances in different samples, which is to check if the population variances are equal and comparable. 
Table 2. Levene's Test of Homogeneity for General Chemistry and Organic Chemistry ASCI and CAEQ surveys

\begin{tabular}{|c|c|c|c|}
\hline Survey & Variables & $\begin{array}{c}\text { General } \\
\text { Chemistry } \\
\text { Sig. }\end{array}$ & $\begin{array}{c}\text { Organic } \\
\text { Chemistry } \\
\text { Sig. }\end{array}$ \\
\hline \multirow{4}{*}{ CAEQ } & Career interest in chemistry & 0.647 & 0.506 \\
& Leisure interest in chemistry & 0.807 & 0.323 \\
& Attitude towards chemistry in society & $\mathbf{0 . 0 0 1 *}$ & 0.105 \\
& Skills of chemists & 0.634 & 0.697 \\
& Attitude towards chemists & 0.934 & 0.817 \\
\hline \multirow{4}{*}{ ASCI } & Fear & 0.266 & 0.637 \\
& Interest and utility & 0.819 & 0.383 \\
& Intellectual accessibility & 0.881 & 0.080 \\
& Anxiety & 0.233 & 0.983 \\
\hline
\end{tabular}

*Related samples Wilcoxon Signed Rank Test, $\mathrm{p}=0.098>0.05$. Retain the null hypothesis.

Table 2 gives the significance values of Levene's test of homogeneity and all of the variables satisfy the null hypothesis except "Attitude towards chemistry in society" from the CAEQ survey. A non-parametric test, Wilcoxon Signed Rank Test satisfies the null hypothesis for this variable, and hence both the POGIL and Control groups have equal variances and are comparable for all the variables in both the CAEQ and ASCI surveys. 
Table 3. Cronbach's Alpha values for General Chemistry and Organic Chemistry ASCI survey

\begin{tabular}{|c|c|c|c|c|c|}
\hline \multicolumn{2}{|c|}{ Course } & $\begin{array}{c}\text { Interest and } \\
\text { utility }\end{array}$ & $\begin{array}{c}\text { Intellectual } \\
\text { accessibility }\end{array}$ & Anxiety & $\begin{array}{c}\text { Emotional } \\
\text { satisfaction }\end{array}$ \\
\hline General & POGIL (post) & 0.733 & 0.731 & 0.702 & 0.711 \\
Chemistry $(\alpha)$ & POGIL (pre) & 0.650 & 0.747 & 0.755 & 0.738 \\
$(\mathrm{~N}=69 / 111)$ & Control (post) & 0.781 & 0.714 & 0.653 & 0.766 \\
& Control (pre) & 0.785 & 0.659 & 0.665 & 0.722 \\
\hline Organic & POGIL (post) & 0.848 & 0.632 & 0.788 & 0.777 \\
Chemistry ( $\alpha$ ) & POGIL (pre) & 0.859 & 0.710 & 0.669 & 0.773 \\
$(\mathrm{~N}=36 / 14)$ & Control (post) & 0.808 & 0.524 & 0.661 & 0.852 \\
& Control (pre) & 0.714 & 0.586 & 0.667 & 0.852 \\
\hline
\end{tabular}

Table 4. Cronbach's Alpha values for General Chemistry and Organic Chemistry CAEQ survey

\begin{tabular}{|c|c|c|c|c|c|c|c|}
\hline \multicolumn{7}{|c|}{ CAEQ } & \multirow[b]{2}{*}{$\begin{array}{c}\text { Self- } \\
\text { Efficacy }\end{array}$} \\
\hline \multicolumn{2}{|l|}{ Course } & $\begin{array}{c}\text { Career } \\
\text { interest } \\
\text { in } \\
\text { chemistry }\end{array}$ & $\begin{array}{c}\text { Leisure } \\
\text { interest in } \\
\text { chemistry }\end{array}$ & $\begin{array}{c}\text { Attitude } \\
\text { toward } \\
\text { chemistry } \\
\text { in society }\end{array}$ & $\begin{array}{l}\text { Skills of } \\
\text { chemists }\end{array}$ & $\begin{array}{c}\text { Attitude } \\
\text { toward } \\
\text { chemists }\end{array}$ & \\
\hline \multirow{4}{*}{$\begin{array}{c}\text { General } \\
\text { Chemistry } \\
(\alpha) \\
(\mathrm{N}=68 / 107)\end{array}$} & $\begin{array}{l}\text { POGIL } \\
\text { (post) }\end{array}$ & 0.852 & 0.536 & 0.954 & 0.844 & 0.650 & 0.960 \\
\hline & $\begin{array}{l}\text { POGIL } \\
\text { (pre) }\end{array}$ & 0.610 & 0.551 & 0.830 & 0.791 & 0.419 & 0.917 \\
\hline & $\begin{array}{c}\text { Control } \\
\text { (post) }\end{array}$ & 0.760 & 0.522 & 0.853 & 0.737 & 0.645 & 0.939 \\
\hline & $\begin{array}{c}\text { Control } \\
\text { (pre) }\end{array}$ & 0.745 & 0.478 & 0.910 & 0.706 & 0.535 & 0.925 \\
\hline \multirow{4}{*}{$\begin{array}{c}\text { Organic } \\
\text { Chemistry } \\
(\alpha) \\
(\mathrm{N}=31 / 13)\end{array}$} & $\begin{array}{c}\text { POGIL } \\
\text { (post) }\end{array}$ & 0.872 & 0.500 & 0.897 & 0.870 & 0.587 & 0.892 \\
\hline & $\begin{array}{l}\text { POGIL } \\
\text { (pre) }\end{array}$ & 0.889 & 0.636 & 0.830 & 0.728 & 0.648 & 0.902 \\
\hline & $\begin{array}{c}\text { Control } \\
\text { (post) }\end{array}$ & 0.802 & 0.802 & 0.951 & 0.917 & 0.427 & 0.894 \\
\hline & $\begin{array}{c}\text { Control } \\
\text { (pre) }\end{array}$ & 0.893 & 0.732 & 0.955 & 0.835 & 0.551 & 0.827 \\
\hline
\end{tabular}

